\title{
Italian Primary Care System: an overview
}

\section{System podstawowej opieki medycznej we Włoszech - przegląd}

\author{
FERDINANDO PETRAZZUOLID-F
}

Department of Clinical Sciences in Malmö, Centre for Primary Health Care Research, Lund University, Malmö, Sweden

A - Study Design, B - Data Collection, C - Statistical Analysis, D - Data Interpretation, E - Manuscript Preparation, $\mathbf{F}$ - Literature Search, $\mathbf{G}$ - Funds Collection

Summary Italian Primary Care System has been modelled after the NHS in UK and was established in 1978. In 2000 Italy's healthcare system was regarded, by a World Health Organization's ranking, as the $2^{\text {nd }}$ best in the world after France; since then, the performance has constantly decreased mainly because of the austerity policy. This austerity policy is not justified by the Official OECD figures which show that Italian Health Care expenditures are below the average in OECD Countries. Quality outcomes almost always show a clear North-South divide in almost all health care sectors. Responsibility for health care is now shared between the central government and 19 regions and 2 autonomous provinces (Trento and Bolzano), which traditionally differ a lot in terms of economic development, per capita income, demography and culture. Disparities can be found in almost any area of health care provision, in health policy making, health care expenditure, quality of health care, public satisfaction and health care services organization. The pros of the Italian Primary Care System are the continuity of care and the universalism; the cons are the crippling bureaucracy, the workload, the lack of basic social benefits for GPs such as subsidized sick leaves and the lack of University Department of Primary Care and finally the absence of any perspective of professional development in the Academic field.

Key words: primary health care, general practice, continuity of care, health care costs.

Streszczenie System podstawowej opieki zdrowotnej we Włoszech był wzorowany na systemie obowiązującym w Wielkiej Brytanii i został ustanowiony w 1978 r. W 2000 r. system opieki zdrowotnej we Włoszech otrzymał 2. miejsce na świecie po systemie francuskim w rankingu Światowej Organizacji Zdrowia. Od tamtej pory jego wydajność stale spada głównie z powodu polityki oszczędnościowej. Prowadzona polityka oszczędnościowa nie jest uzasadniona przez oficjalne dane OECD, które pokazują, że wydatki włoskiej służby zdrowia są poniżej średniej w krajach OECD. Efekty jakościowe prawie zawsze pokazują wyraźny podział na północ i południe w niemal wszystkich sektorach opieki zdrowotnej. Odpowiedzialność za opiekę zdrowotną jest obecnie podzielona między rządem centralnym a 19 regionami i 2 autonomicznymi prowincjami (Trento i Bolzano), które od dawna różnią się bardzo pod względem rozwoju gospodarczego, dochodów na mieszkańca, demografii i kultury. Różnice można znaleźć w prawie każdej dziedzinie opieki zdrowotnej, w kształtowaniu polityki zdrowotnej, wydatkach na opiekę zdrowotną, jakości opieki zdrowotnej, satysfakcji z korzystania z publicznej służby zdrowia i organizacji usług opieki zdrowotnej. Zaletami systemu podstawowej opieki zdrowotnej we Włoszech są ciagłość opieki i uniwersalizm; wadami są: rozdęta biurokracja, obciążenie pracą, brak podstawowych świadczeń socjalnych dla lekarzy, takich jak płatne zwolnienia lekarskie oraz brak wydziału zdrowia publicznego na uniwersytecie, a także brak jakiejkolwiek perspektywy rozwoju zawodowego na poziomie akademickim.

Słowa kluczowe: podstawowa opieka zdrowotna, medycyna rodzinna, ciągłość opieki, koszty opieki zdrowotnej.

\section{Background}

The Italian National Health Service (NHS) is a public system that guarantees health care for all citizens (all citizens are equal and enjoy equal rights), funded through general tax revenues (taxes) and prescription charges. Italian Primary Care System has been modelled after the NHS in UK, and replaced a Bismarckian system of health insurance funds in 1978. In 2000 Italy's healthcare system was regarded, by World Health Organization's ranking, as the $2^{\text {nd }}$ best in the world after France [1]; since then, the performance has constantly decreased mainly because of the austerity policy which has affected also the Italian Health Care System [2]. This austerity policy is not justified by the official OECD figures which show that Italian Health Care expenditures are below the average in OECD Countries [3] [Fig. 1].
Italian NHS is based on the principles of universalism, comprehensiveness and solidarity, with the aims of guaranteeing uniform provision of comprehensive care throughout the Country [4].

The health status of Italy's population as a whole has thus improved and this is in line with that of other EU countries. However, despite these general improvements, disparities can be highlighted among regions. There is indeed a substantial regional variability in health care organization and provision. Responsibility for health care is now shared between the central government and 19 regions and 2 autonomous provinces (Trento and Bolzano), which traditionally differ a lot in terms of economic development, per capita income, demography and culture. Disparities can be found in almost any area of health care provision, in health policy making, health care expenditure, quality of health care, public satisfaction and health care services organization [5]. 


\begin{tabular}{|c|c|c|c|c|c|c|c|c|c|c|c|c|c|c|c|c|}
\hline 1 & \multicolumn{16}{|l|}{ HEALTH EXPENDITURE } \\
\hline 2 & Current expenditure on health, \% & & & & & & & & & & & & & & & \\
\hline 3 & & & & & & & & & & & & & & & & \\
\hline 4 & & 2001 & 2002 & 2003 & 2004 & 2005 & 2006 & 2007 & 2008 & 2009 & 2010 & 2011 & 2012 & 2013 & 2014 & \begin{tabular}{|c|}
2013 \\
(or nearest year)
\end{tabular} \\
\hline $\mid \begin{array}{l}4 \\
5\end{array}$ & Australia & 7.7 & $7.9^{\circ}$ & 7.9 & 8.1 & $8.0^{\circ}$ & $8.0^{\circ}$ & 8.1 & 8.3 & 8.6 & $8.5^{\prime}$ & 8.6 & $8,8$. & & & \\
\hline 6 & Austria & 9,3 & 9,4 & 9,6 & 9,6 & 9,6 & 9,5 & 9,5 & 9,6 & 10,1 & 10,1 & 9,9 & 10,1 & 10,1 &.. & 10,1 \\
\hline 7 & Belgium & 8,1 & 8,3 & 9,1 & 9,1 & 9,0 & 8,9 & 9,0 & 9,4 & 10,1 & 9,9 & 10,1 & 10,2 & 10,2 . & & 10,2 \\
\hline 8 & Canada & 8,7 & 9,0 & 9,1 & 9,1 & 9,1 & 9,3 & 9,4 & 9,5 & 10,6 & 10,6 & 10,3 & 10,2 & 10,2 & $10,0^{\circ}$ & 10,2 \\
\hline 9 & Chile & 6,5 & $6,5^{7}$ & 7,3 & 6.9 & 6.6 & 6.1 & 6,3 & 6,8 & 7,3 & 6,9 & 6,9 & 7,1 & 7,4 . & & 7,4 \\
\hline 10 & Czech Republic & 5,9 & 6,2 & 6,6 & 6.4 & 6.4 & 6,2 & 6,0 & 6,4 & 7,3 & 6,9 & 7,0 & 7,1 & $7,1$. & & 7,1 \\
\hline 11 & Denmark & 8,4 & 8,7 & $8,9^{\circ}$ & 9,0 & 9,1 & 9,2 & 9,3 & 9,5 & 10,7 & 10,4 & 10,2 & 10,4 & 10,4 . & & 10,4 \\
\hline 12 & Estonia & 4,8 & 4,7 & 4,9 & 5,1 & 5.0 & 4.9 & 5,0 & 5,7 & 6,6 & 6,1 & 5,7 & $5,8^{8}$ & $6,0$. & & 6,0 \\
\hline 13 & Finland & 6,8 & 7,2 & 7,5 & 7,5 & 7.7 & 7,6 & 7.4 & 7,6 & 8,3 & 8,2 & 8,2 & 8,5 & 8,6 & $8,7^{\prime \prime}$ & 8,6 \\
\hline 14 & France & 9,7 & 10.0 & $10,0^{\circ}$ & 10,1 & 10.2 & 10.1 & 10.0 & 10,2 & 10,9 & 10,8 & 10,7 & 10,8 & 10,9 . & & 10,9 \\
\hline 15 & Germany & 9,9 & 10,1 & 10,3 & 10,1 & 10,3 & 10,1 & 10,0 & 10,2 & 11,1 & 11,0 & 10,7 & 10,8 & 11,0 & $11,1^{11}$ & 11,0 \\
\hline 16 & Greece & 8,0 & 8,3 & 8,2 & 80 & 9.0 & 9.0 & 9,1 & 9,8 & 9,8 & 9,2 & 9,7 & 9,1 & $9,2$. & & 9,2 \\
\hline 17 & Hungary & 6,9 & 7,1 & 8,2 & 7,8 & 8,1 & 7,9 & 7,3 & 7,2 & 7,4 & 7,7 & 7,7 & 7,5 & 7,4 . & & 7,4 \\
\hline 18 & Iceland & 8,9 & 9,6 & $10,1^{4}$ & $9,5^{4}$ & $9,2^{4}$ & $8.9^{\circ}$ & $8,7^{4}$ & 8,7 & 9,1 & $8,8^{\prime}$ & 8,6 & $8,7^{\prime \prime}$ & 8,7 & $8,8^{7}$ & 8,7 \\
\hline 19 & Ireland & 6,1 & 6.3 & 6.6 & 6.8 & 6.9 & 7.0 & 7,2 & 8,3 & 9,2 & 8,5 & 8,0 & 8,1 . & & & 8,1 \\
\hline 20 & Israel & 7,3 & 7,2 & 7,2 & 7,1 & 7,2 & 7,0 & 7,0 & 7,0 & 7,1 & 7,0 & 7,0 & $7,4^{1}$ & $7,5^{\circ}$ & & 7,5 \\
\hline 21 & Italy & 7,8 & 7,9 & 7,9 & 8.2 & 8,4 & 8,5 & 8,2 & 8,6 & 9,0 & 8,9 & 8,8 & $\begin{array}{l}1,4 \\
8,8\end{array}$ & 8,8 & $8,9^{\circ}$ & 8,8 \\
\hline 22 & Japan & 7,6 & 7,7 & 7,9 & 7.9 & 8.1 & 8.1 & 8,2 & 8,5 & 9,4 & 9,5 & 10,0 & 10,1 & $10,2^{\prime}$ & $10,2^{n}$ & 10,2 \\
\hline 23 & Korea & 4,5 & 4,3 & 4,7 & 4.7 & 5.0 & 5.4 & 5,6 & 5,8 & 6,3 & 6,5 & 6,5 & 6,7 & 6,9 & $7, \overline{1}$ & 6,9 \\
\hline 24 & Luxembourg & 6.5 & 6.8 & 7.1 & 7.4 & 7.2 & 6.8 & 6.4 & 6.6 & 7.5 & 7.2 & 6.8 & 6.6 . & & & 6.6 \\
\hline $\begin{array}{l}24 \\
25\end{array}$ & Mexico & $5,3^{4}$ & 5,4 & 5.9 & 6.0 & 5.9 & 5.7 & 5,8 & 5,9 & 6.4 & 6,2 & 5,9 & 6,1 & 6.2 . & & 6.2 \\
\hline 26 & Netherlands & 7,4 & 8,0 & 8,5 & 8.6 & $9.5^{\prime \prime}$ & 9.4 & 9,4 & 9,6 & 10,3 & 10,4 & 10,5 & 11,0 & 11,1 & $11,1^{\pi}$ & 11,1 \\
\hline 27 & New Zealand & 7,6 & $7,9^{4}$ & 7,7 & 7,9 & 8.2 & 8.6 & 8,4 & 9,2 & 9,7 & 9,7 & $9,7^{7}$ & 9,8 & $9,5$. & & 9,5 \\
\hline 28 & Norway & $8,0^{\circ}$ & 9,0 & 9,2 & 8.8 & 8,3 & 7,9 & 8,1 & 8,0 & 9,1 & 8.9 & 8,8 & 8.8 & 8,9 & $9,2^{n}$ & 8,9 \\
\hline 29 & Poland & 5,7 & 6.1 & 6.0 & 5.9 & 5.8 & 5.8 & 5,9 & 6.4 & 6.6 & $6,5^{7}$ & 6,3 & 6,3 & 6.4 . & & 6.4 \\
\hline 30 & Portugal & 8,4 & 8,5 & 8,9 & 9,3 & 9,4 & 9,1 & 9,1 & 9,3 & 9,9 & 9,8 & 9,5 & 9,3 & $9,0^{\circ}$. & & 9,0 \\
\hline 31 & Slovak Republic & 5,3 & 5,5 & 5.4 & 6.5 & 6.6 & 6.9 & 7,2 & 7,5 & 8.5 & $\begin{array}{l}7,8^{7} \\
\end{array}$ & 7,5 & 7,7 & 7,6 & & 7,6 \\
\hline 32 & Slovenia & 8.4 & $8,0^{\circ}$ & 8,1 & 7,9 & 8,0 & 7,8 & 7,5 & 7,8 & 8,6 & 8,6 & 8,5 & 8,7 & 8,7 & $8,6^{\prime \prime}$ & 8,7 \\
\hline 33 & Spain & 6,8 & 6,8 & $7,7^{7}$ & 7,8 & 7,8 & 7,9 & 8,0 & 8.4 & 9,1 & 9.1 & 9.0 & 8.9 & & & 8,9 \\
\hline 34 & Sweden & $8.0^{\circ}$ & 8.4 & 8.5 & 8.3 & 8.3 & 8.2 & 8.1 & 8.3 & 8.9 & 8,5 & $10.6^{\circ}$ & 10.8 & 11.0 & & 11.0 \\
\hline 35 & Switzerland & $9,7^{\prime \prime}$ & 10,1 & $10.4^{4}$ & 10.4 & $10.3^{7}$ & $9.8^{\prime}$ & $9.6^{\prime}$ & $9.8^{\circ}$ & 10.4 & $10,5^{7}$ & $10,6^{\prime}$ & $11,0^{\circ}$ & $11,1^{\circ}$ & 11,1 & 11,1 \\
\hline $36=$ & Turkey & 5,0 & 5,2 & 5,2 & 5,1 & 5,1 & 5.4 & 5,5 & 5,5 & 5,8 & 5,3 & 5,0 & 5,0 & $5,1$. & & 5,1 \\
\hline 37 & United Kingdom & 6,6 & 6,9 & 7,1 & 7,3 & 7.4 & 7,6 & 7,6 & 7,9 & 8,8 & 8,6 & 8,5 & 8,5 & 8,5 . & & 8,5 \\
\hline 38 & United States & 13,2 & 14,0 & 14,5 & 14,6 & 14.6 & 14.7 & 14.9 & 15,3 & 16.4 & 16,4 & 16,4 & 16,4 & 16.4 & & 16,4 \\
\hline 397 & OECD AVERAGE & & & & & & & & & & & & & & & 8.9 \\
\hline & Frequently Requested Data & Irrent & expendi & diture, \% & \% GDP & Curr ex & $\operatorname{xp}$, per ca & capita US & S\$PPP & Curre & $\exp , p$ & per capit. & ta, AAGR & & ublic ex & Public \\
\hline
\end{tabular}

Figure 1. Health care expenditure - GDP

\begin{tabular}{l} 
REGIONE CAMPANIA \\
$\begin{array}{l}\text { REGIONE CAMPANIA - ASL CASERTA } \\
\text { Prescrizione }\end{array}$ \\
$\begin{array}{l}\text { In A I A R P Percorso assistenziale per i pazienti in cura con i farmaci Ex D.M. 22/12/2000 all. } 2 \\
\text { 1 - Centro Prescrittore }\end{array}$ \\
\hline Centro Prescrittore: CASA DI CURA SAN MICHELE - Cardiologia \\
\hline Medico Prescrittore: DE SIMONE ANTONIO (NA025970) \\
\hline
\end{tabular}

\section{2 - Paziente}

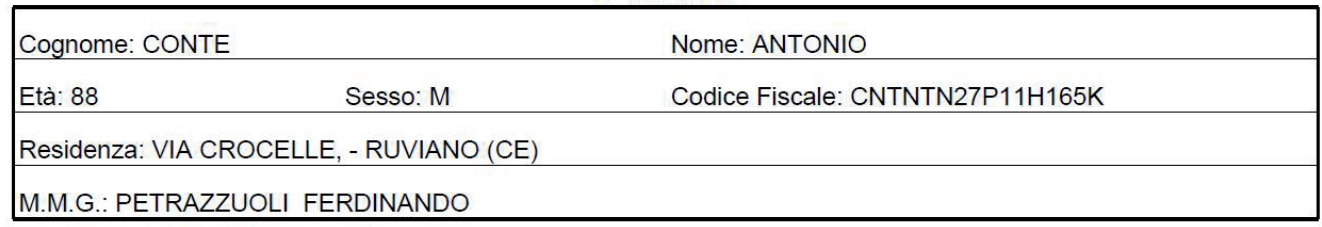

3 - Diagnosi

999.9.999.9 ALTRO - -

4 - Piano Terapeutico

\begin{tabular}{|l|c|r|}
\hline Tipo Prescrizione: PROSECUZIONE CURA & Ciclo Terapeutico \\
\hline Forma Farmaceutica & Posologia & 365 giorni \\
\hline CPR $2,5 \mathrm{mg}$ & n. 2 unità ogni 1 giorno/i & \\
\hline Principio Attivo: APIXABAN & & \\
\hline
\end{tabular}

\section{5 - Condizioni Cliniche}

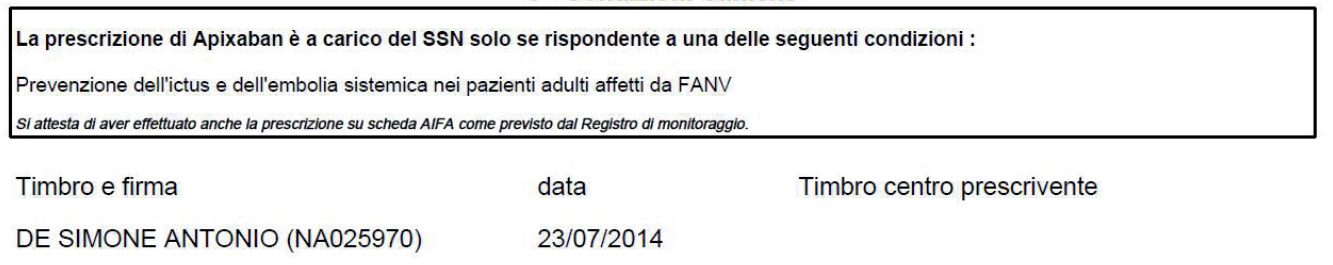

\section{SCADENZA PRESCRIZIONE 23/07/2015}

Figure 2. Piano Terapeutico Fictious patient 


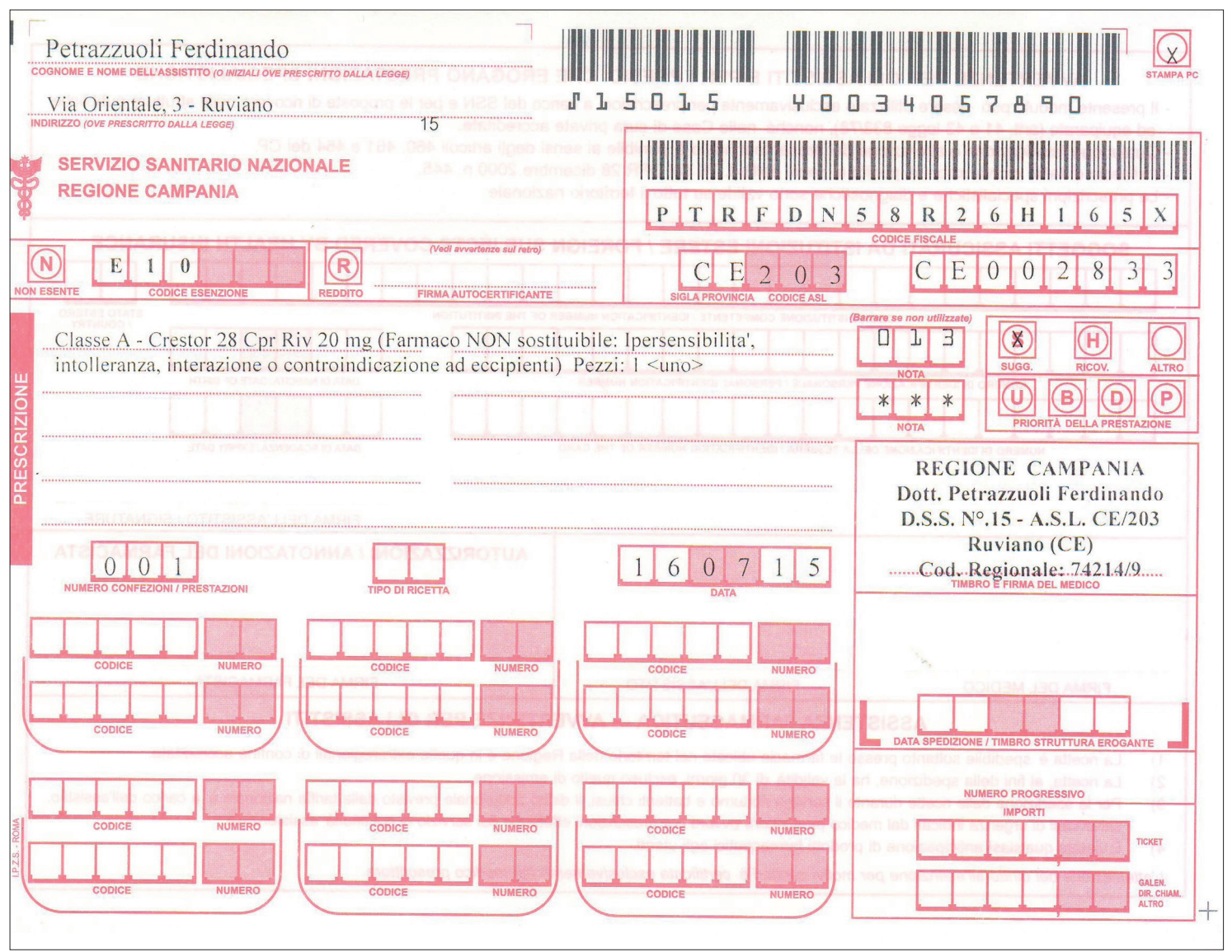

Figure 3. Italian red form fictitious patient

Over the years, the Italian NHS has presented many major problems: it is in fact "plagued with crippling bureaucracy, mismanagement, a general disorganization and long waiting lists" [6]. Quality outcomes almost always show a clear North-South divide in almost all health care sectors.

The central government defines a national minimum statutory benefits package to be offered to all residents in every region - the "essential levels of care". The 19 regions and 2 autonomous provinces have responsibility for the organization and delivery of health services through local health units (LHUs). The SSN covers all citizens and legal foreign residents. Coverage is automatic and universal. Since 1998, illegal immigrants have been granted access to basic services.

\section{Services}

Inpatient care and primary care are free at the point of treatment. However, copayments are required for diagnostic procedures, specialists, and prescription drugs. The size of such copayments has crept steadily upward over the past decade and now runs as high as 30 percent for some services.

The following services are offered to all residents: pharmaceuticals, inpatient care, preventive medicine, ambulatory care, home care, primary care. Cosmetic surgery is not offered for free and there are services which are only partially covered: orthodontics and laser eye surgery.

Only a limited number of drugs are reimbursed (partially or totally). Many drugs which are reimbursed in most European Countries are not free in Italy: for example benzodiazepins, all drugs for venous disease except low molecular weight heparin, antispasmodics in tables (antispasmodics in injection are reimbursed), cough medicines, paracetamol, aspirin, many pain killers et cetera. The rules for this are established by the Italian agency for drugs AIFA with the assumption that only drugs with type A evidence in the Evidence Based Medicine can be offered for free by the public system, but there also other reasons mainly linked to the austerity policy [7].

For some categories of drugs, usually the new and expensive ones such as incretins, new oral anticoagulants, drugs for dementia, atypical antipsychotics, GPs are not allowed to prescribe them directly and a "therapeutic plan form" completed by a public secondary care specialist is mandatory (Fig. 2); these prescriptions must follow strict national clinical guidelines and are thoroughly monitored [8].

Dental health care is included in the essential level of care for specific populations such as children (0-16 years old), vulnerable people (disabled people, people with HIV, people with rare diseases), and individuals who need dental health care in some urgent/emergency cases. For the rest of the population, dental care is generally not covered and is an "expensive" out of pocket expenditure.

\section{Cost-sharing}

Diagnostic investigations and consultations and medicines can be requested either by a GP or by a public sector specialist who are the only allowed to use the special red form needed to have them for free or partially subsidized (Fig. 3). Patients pay for the total cost of an investigation up to a ceiling determined by law - currently, the ceiling stands at $€ 36.15$. Therefore, a patient who receives two separate prescriptions (e.g., a magnetic resonance imaging scan and a laboratory test) after a visit has to pay the first $€ 36.15$ for each prescription. To address rising public debt, in July 2011, the government introduced, along with other economic initiatives, an additional $€ 10,00$ copayment for each prescription. Copayments have also been applied 
to outpatient drugs at the regional level and, since 2007, a $€ 25,00$ copayment has also been introduced for the "inappropriate" use of emergency services.

Primary and inpatient care are free at the point of use. Exemptions from copayment are applied to people aged over 65 or children less than 6 who live in households with a gross income below a nationally defined threshold (approximately $€ 36,000$ ); people with severe disabilities, are also exempted from any cost-sharing. People with chronic or rare diseases, people who are HIV-positive, and pregnant women are exempted from cost-sharing but only for the treatment related to their condition. Most screening services are provided free of charge.

\section{Primary care doctors' wages}

General practitioners and primary care paediatricians are paid on a capitation basis. The NHS can also pay additional allowances for the delivery of planned care to specific patients (e.g., home care for chronically ill patients), for reaching performance targets (similar to the incentives in the Quality and Outcome Framework in UK), or for delivering additional treatments (e.g., medications, flu vaccinations) and are regulated under national and regional contracts. Capitation is adjusted for age and accounts for approximately 70 percent of the overall income. The variable portion comprises fee-for-service payment for specific treatments, including minor surgery, home care, preventive activities, and taking care of chronically ill patients. The payment levels, duties, and responsibilities of GPs are determined in a collective agreement signed every three years by consultation between the central government and the GPs' trade unions. The majority of GPs operate in solo practices, although the central government and the regions have offered economic incentives to encourage group practices and greater integration between GPs and social care, home care, health education, and environmental health services. In 2010, there were approximately 53,500 general practitioners and primary care paediatricians $(33.3 \%)$ and 107,000 hospital clinicians $(66.7 \%)$ for nearly 60 million people. Patients are required to register with a gatekeeping GP, (from 0 to 6 years old is mandatory the registration with a primary care paediatrician, from 6 to 12 either with a family doctor or a primary care paediatrician). People may choose any physician whose list has not reached the maximum number of patients allowed (1500 for GPs and 800 for paediatricians) and may switch at any time to another GP or another paediatrician in case of dissatisfaction.

\section{Outpatient specialist care}

Outpatient specialist care is generally provided by LHU or by public and private accredited hospitals under contractual agreement with an LHU. Once referred, patients are given free choice of any public or private accredited hospital. Ambulatory specialists are generally paid on a per-hour basis, while hospital-based physicians are salaried employees.

\section{Out of hours care}

Officially, between 8pm and 8am on weekdays, and from Saturday 10 am to Monday 8am patients have to refer to an "on call out of hours service" called "Guardia Medica". Recently government and GP associations have agreed to implement a model where GPs, specialists, and nurses coordinate to ensure 24-hour access and avoid unnecessary use of hospital emergency departments. The general structure of the model has been outlined in the collective agree- ment; there is no additional payment for the provision of this care. Implementation is uneven across regions. Out of hours centres are generally located in LHU-owned premises. Following examination and initial treatment, the doctor can prescribe medication, issue employees' medical certificates, and recommend hospital admission. Unfortunately reports on a patient's visit by the out of hours service is not routinely sent to the patient's GP.

\section{Long-term care}

In Northern Italy patients are generally treated in residential or semi-residential facilities, or in community home care. Residential and semi-residential services provide nurses, physicians, specialist care, rehabilitation services, and medical therapies and devices. All these facilities are hardly available in Southern Italy. Patients must be referred in order to receive residential care. Cost-sharing for residential services varies widely according to region, but is generally determined by patient income. Community home care is funded publicly, whereas residential facilities are managed by a mixture of public and private, "for profit" and "non profit" organizations. Unlike residential and semi-residential care, community home care is not designed to provide physical or mental care services but rather to enhance a patient's autonomy by providing additional assistance throughout a course of treatment or therapy. In spite of government provision of residential and home care services, long-term care in Italy has traditionally been characterized by a low degree of public financing and provision as compared with other European countries.

Until recently, palliative care was very limited and was concentrated mainly in Northern Italy. Much was left to the efforts of voluntary organizations, which still play a crucial role in the delivery of these services. Although much still needs to be done to ensure the diffusion of homogeneous palliative care services, a national policy on palliative care has been in place since the end of the 1990s and has contributed to an increase in palliative care services such as hospices, day-care centrrs, and palliative care units within hospitals.

\section{Solo practices and multipractices}

In the past few years general practice has witnessed a transformation, with the solo practice model being progressively modified by new organizational forms (networks, groups, etc.), particularly in the northern part of the country. Recent legislation encourages multidisciplinary teams to work in three ways: basic group practice, where GPs from different offices share clinical experiences, develop guidelines, and participate in workshops that assess performance; network group practice, which functions like base group practice but allows GPs to access the same electronic medical record system; and advanced group practice, where GPs share the same office and electronic medical record system, and are able to provide care to patients beyond individual catchment areas.

Also in recent years, significant progress have been made into better integration of health and social care services. The community home care scheme was founded as part of the National Health Plan for 1998-2000, and establishes a home care network that integrates the competencies of nurse, GP, and specialist physician with the needs and involvement of the family. GPs oversee the home care network, liaise with social workers and other sectors of care, and take responsibility for patient outcomes.

In some regions GPs work in multi-specialty groups involving specialists, nurses, and social workers. Shifting to 
this new organizational arrangement nevertheless requires considerable efforts, given that, traditionally, Italian GPs have been used to working in solo practices, furthermore this is very difficult to implement in rural areas.

\section{Electronic medical records}

Some regions have developed computerized networks connecting physicians, primary care paediatricians, hospitals, and territorial services to facilitate communication among health care professionals and to improve continuity of care. These networks allow automatic transfer of patient registers, services supplied to patients, prescriptions for specialist visits and diagnostics, and laboratory and radiology test outcomes.

\section{Continuous medical education}

All doctors under contract with the SSN must be certified, and all SSN staff participate in a compulsory continuing education program.

\section{University and Primary Care}

In Italy there are no Academic Departments of Primary Care. The course to become future GP is a Regional Course organized by the Regional Health Care System under national rules. GPs are involved as tutors and sometimes as teachers in the seminars for future GPs in their vocational training; only in a few universities, they are also involved in seminars and as tutors in the undergraduate medical education but with no official recognition of an Academic position within the university. So at the moment Italy is lagging behind in this field and the competencies described by the European Academy of Teachers in General Practice and Family Medicine (EURACT) regarding the minimal core curriculum for FM/GP in undergraduate medical education, such as patient centeredness, holistic approach and bio-psycho-social model are definitely not addressed in most of the Italian universities. [9]

\section{Conclusions}

There are pros and cons of the Italian Primary Care System. Patients are free to access their family doctor whenever they require medical attention. In main areas family doctors usually see patients without appointments. Although this system has some advantages in terms of continuity of care, nothing can be done to stop patients from attending at all hours for minor diseases and the phenomenon of "frequent attenders" is largely widespread.

Continuity of care is provided as there is patient registration and almost all family doctors have electronic medical records system. Unfortunately, much of GPs work involves a lot of bureaucracy: repeated prescriptions and transcriptions of specialists' prescriptions, hundreds of certificates and so on. GPs in Italy have to pay directly for all the equipment and premises of their surgeries.

Another major problem is the lack of basic social benefits for Italian GPs such as subsidized sick leaves: Italian family doctors have to pay directly their locum also for maternal leaves, study leaves or when they decide to go on holiday. The absence of academic departments of primary care is certainly one of the priorities which should be addressed in the nearest future.

Source of funding: The source of financing the article is author's own resource, no external funding.

Conflict of interest: The author declares no conflict of interests.

\section{References}

1. Country statistics and global health estimates by WHO and UN partners. Italy: WHO statistical profile. WHO, January 2015 [cited 25.07.2015]. Available from URL: http://www.who.int/countries/ita/en/.

2. Björnberg A. Health Consumer Power House. Euro Health Consumer Index. Report. 2014 [cited 20.07.2015]. Available from URL: http://www.healthpowerhouse.com/files/EHCI_2014/EHCI_2014_report.pdf.

3. OECD Health Statistics 2015 - Frequently Requested Data [cited 23.07.2015]. Available from URL: http:// http://www.oecd. org/els/health-systems/health-data.htm.

4. Ferré F, de Belvis AG, Valerio L, et al. Italy: Health System Review. Health Systems in Transition 2014; 16(4): 1-168. Available from URL: http://www.euro.who.int/_data/assets/pdf_file/0003/263253/HiT-Italy.pdf.

5. Thomson S, Osborne R, Squires D, et al. International Profiles of Health Care System, 2013. The Commonwealth Fund 2013: 11. Available from URL: http://www.commonwealthfund.org/ /media/files/publications/fund-report/2013/nov/1717_thomson_intl_profiles_hlt_care_sys_2013_v2.pdf.Tanner M. The Grass Is Not Always Greener: A Look at National Health Care Systems Around the World. Policy Analysys 2008 March; 613. Accessed at the: The Cato Institute. Washington. Available from URL: http://object.cato.org/sites/cato.org/files/pubs/pdf/pa-613.pdf.

6. The Italian Medicines Agency (AIFA). Pricing and Reimbursement [cited 15.06.2015]. Available from URL: http://www.agenziafarmaco.gov.it/en/content/pricing-and-reimbursement.

7. The Italian Medicines Agency (AIFA). Post-Marketing surveillance [cited 14.06.2015]. Available from URL: http://www.agenziafarmaco.gov.it/en/content/post-marketing-surveillance.

8. Tandeter $\mathrm{H}$, Carelli F, Timonen M, et al. A 'minimal core curriculum' for Family Medicine in undergraduate medical education: a European Delphi survey among EURACT representatives. Eur J Gen Pract 2011; 17(4): 217-220.

Address for correspondence:

Dr Ferdinando Petrazzuoli, MD, MSc

Via Orientale3 81010 Ruviano (CE) Italy

Tel.: +390823860032

Mobile: +393471273910

E-mail: ferdinando.petrazzuoli@gmail.com

Received: 24.06.2015

Revised: 02.08.2015

Accepted: 03.08.2015 